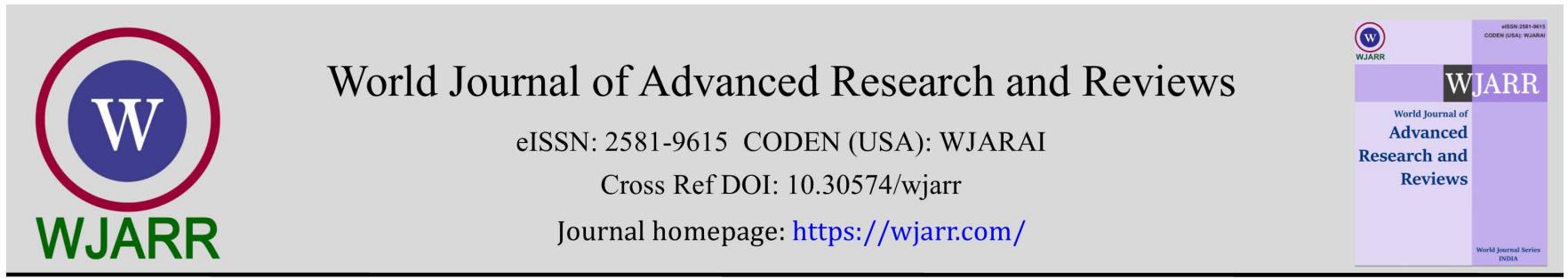

(RESEARCH ARTICLE)

Check for updates

\title{
A preliminary report on bioavailability of Ayurvedic Gold Bhasma with four different accompanying media [anupana]
}

\author{
Trupti Patil 1,* and Asmita Wele ${ }^{1}$ and Sangram Patil 2 \\ ${ }^{1}$ Department of Rasashastra and Bhaishajyakalpana, College of Ayurved, Bharati Vidyapeeth (Deemed to be University), \\ Pune 411043, Maharashtra, India \\ ${ }^{2}$ Centre for food testing, Bharati Vidyapeeth (Deemed to be University), Erandwane, Pune, 411038, Maharashtra, India
}

World Journal of Advanced Research and Reviews, 2021, 12(03), 033-044

Publication history: Received on 18 September 2021;revised on 25 October 2021;accepted on 27 October 2021

Article DOI: https://doi.org/10.30574/wjarr.2021.12.3.0540

\begin{abstract}
Background: Gold bhasma [Swarnabhasma] is a ancient Ayurvedic medicine used for rejuvenation and longevity. This is a preliminary attempt to study the bioavailability of this medicine.

Objectives: It was aimed to estimate comparative bioavailability of gold bhasma up to five hours after oral dose with four different anupana.

Materials and methods: In this in vivo study, 30 healthy human participants were allocated randomly into five groups having six individuals each. Gold bhasma in $30 \mathrm{mg}$ dose was administered orally with four different anupana viz honey [2.5 gm], black pepper-ghee combination [250 $\mathrm{mg}$ and $2.5 \mathrm{gm}$ respectively], lactose [250 $\mathrm{mg}$ ], glucose [250 mg], and plain to participants in each group. Blood samples were collected at 0, 1, 3 and 5 hours after dose. Gold levels in blood were assessed by inductively coupled plasma mass spectrometry [ICP-MS].
\end{abstract}

Results: Gold levels in all blood samples were in traces. Average $\mathrm{C}_{\max }$ was 0.002333 microgram of gold per liter and $\mathrm{T}_{\text {max }}$ was at 3 hours for honey anupana, showing maximum $\mathrm{C}_{\max }$ among all groups.

Conclusions: Preliminary results indicate that bioavailability of gold from gold bhasma may be less than $0.01 \%$ upto first five hours. Gold bhasma mixed with honey resulted in attainment of maximum $\mathrm{C}_{\max }$. It is evident that accompanying media [anupana] play an important role in absorption of gold bhasma.

Keywords: Bioavailability; Gold bhasma; Swarnabhasma, Ayurveda, Pharmacokinetics

\section{Introduction}

Gold is a noble metal, known to mankind since most ancient times. The well-known Ayurvedic compendium Charaksamhita (The pre $2^{\text {nd }}$ century CE text) has reported anti-toxic action of gold particles [1]. Gold is used in Ayurvedic medicine, in the form of gold bhasma (Swarnabhasma / calcined gold). However its exact pharmacokinetics not known so far. Pharmacokinetics deals with the science that deals with rate of absorption, extent of absorption, rates of distribution among body compartments, rate of elimination, and related phenomena. Bioavailability is the first aspect in pharmacokinetics. Considering the therapeutic potential of gold bhasma [2,3], preliminary exploration of its bioavailability was carried out. There are various approaches for such studies [4 Remington's The science and practice of pharmacy, $21^{\text {st }}$ edition, pp 1038]. In the present study an in vivo test in humans has been conducted in which the

\footnotetext{
${ }^{*}$ Corresponding author: Trupti Patil

Department of Rasashastra and Bhaishajyakalpana, College of Ayurved, Bharati Vidyapeeth (Deemed to be University), Pune 411043, Maharashtra, India.

Copyright (C) 2021 Author(s) retain the copyright of this article. This article is published under the terms of the Creative Commons Attribution Liscense 4.0.
} 
active drug substance is measured in blood or plasma. Considering the possibility of gold getting inside the blood cells, whole blood has been tested after acid digestion.

Bioavailability study is the first step in understanding pharmacokinetics of drug. Orally administered drugs need to be absorbed and undergo first pass metabolism before reaching in systemic circulation to reach at target tissue or organs. Bioavailability is the rate and extent to which a drug is absorbed in systemic circulation. The systemic absorption of an orally administered solid drug is dependent on transfer of the drug molecule across the membrane lining the GIT into the systemic circulation.

The present study is a novel approach in field of Ayurveda. This paper is based on study of single oral dose of gold bhasma plain and with four accompanying substances viz. anupana, and estimation of blood gold levels in blood up to five hours. In this preliminary study, considering the ethical issues in human subjects related to multiple times blood sample withdrawal, we have investigated only up to first 5 hours after dose administration to check the swiftness of absorption. Our previous pilot study showed that the $\mathrm{T}_{\max }$ for the same drug was achieved at nearly 2 hours, and there was a decline in gold level after 3 hours [5].

In general oral bioavailability of gold compounds and gold nanoparticles is low. In recent past gold compounds viz. auranofin and gold sodium theomalate were used for treatment of arthritis, but they are associated with incidences of adverse effects [6]. Auranofin inhibits the release of inflammatory mediators from human macrophages, basophils, and pulmonary mast cells. The pharmacokinetics of auranofin has been explored to an extent. It is known that only $15-25 \%$ of orally administered dose of auranofin is absorbed [7]. Gold sodium theomalate was used as intramuscular injection. These two anti-arthritic drugs are not used presently due to adverse drug reactions. On the other hand in recent years modern gold nanoparticles have been investigated for their anti- cancer action and also bioavailability [8]. It is known that a significant limitation of gold nanoparticles currently is their low absorption efficiencies in the gastrointestinal (GI) tract following oral administration [8].

Gold bhasma of Ayurveda is used commonly either mixed with Anupana [specialized accompanying medicaments] or as a part of compound formulations. Ayurvedic drugs are administered by specialized drug delivery methods. Around 60 different accompanying medicaments [anupana] are described in texts for gold bhasma oral administration [9]. Honey is a most commonly used accompanying medium, with its mention in Sushrutsamhita [10] while black pepper mixed with ghee is recommended in the text Rasaratnasamucchay [11]. The traditional media are commonly used by Ayurvedic physicians. However, glucose and lactose which are sugar and milk derivatives; are also used as diluents for gold bhasma as its difficult to measure the $15 \mathrm{mg}$ or $30 \mathrm{mg}$ dose. In present study lactose and glucose are compared with traditional media viz. honey and black pepper-ghee, in view of resultant bioavailability of gold bhasma particles. The intention was to assess if the absorption from single oral dose in 30 healthy human participants and check if the bioavailability of the bhasma is affected by accompanying medium of administration.

\subsection{List of abbreviations}

$\mathrm{Au}-$ Gold

Ppb- parts per billion

$\mathrm{C}_{\max }$-The peak concentration that a drug achieves in a specified compartment after the drug has been administrated and before administration of a second dose

$\mathrm{C}_{\min }-\mathrm{C}_{\min }$ is the minimum (or trough) concentration that a drug achieves after dosing.

$\mathrm{T}_{\max }-$ The amount of time that a drug is present at the maximum concentration in blood.

GIT- gastrointestinal tract

\section{Material and methods}

\subsection{Gold bhasma (investigational product)}

Gold bhasma was procured from GMP approved manufacturing company 'Shree Dhootapapeshwar Limited' (Panvel, India), manufactured according to formulation number 8357 from text Bharat Bhaishajya Ratnakar [12]. This formulation has been manufactured by specific process which includes repeated incinerations of amalgam of 
ingredients viz shuddha swarna [gold], shuddha parad [mercury], shuddha gandhak [sulfur], nimbu swaras [lemon juice]. The drug is light brown colored powder characterized by Varitaratva ie not sinking when kept over still water surface. The investigated sample of gold bhasma contained $95 \%$ pure gold, assessed by gravimetric method [13 ref: Vogel's textbook of quantitative chemical analysis].

\subsection{Procurement and authentication of anupana [accompanying media or vehicle drugs for gold bhasma]}

four anupanas have been used viz. i] honey, ii] black pepper and ghee, iii] lactose and IV] glucose

\subsection{Analysis of honey}

Honey were purchased from authentic source in Pune and tested in certified laboratory. It had madhura-kașāya rasa, light reddish brown colour, and mild aromatic fragrance, smooth and sticky consistency. A cotton wick soaked in honey was ignited and it was observed that it burnt without crepitating noise.

Black pepper powder [Piper nigrum L.] was purchased from authentic source in Pune and was authenticated by HPTLC and physicochemical parameters according to Ayurvedic Pharmacopoea of India from certified drug testing laboratory.

\subsection{Standard piperine}

Process specifications for HPTLC: Mobile Phase was Toluene: Methanol: Glacial Acetic Acid (8: 1.5: 0.5). Standard Preparation was done by dissolving $1 \mathrm{mg}$ of piperine in $1 \mathrm{ml}$ methanol (1000 ppm)

\subsection{HPTLC of black pepper}

Process specifications for HPTLC of black pepper

Sample was prepared by dissolving 5 gm sample of black pepper powder in $50 \mathrm{ml}$ of Methanol. $0.1 \mathrm{ml}$ of extract was diluted with $0.9 \mathrm{ml}$ of Methanol. Mobile Phase was Toluene: Methanol: Glacial acetic acid (8: $1.5: 0.5$ ).

\section{Analytical tests of cows ghee}

Pure cow's ghee was purchased from authentic source which is prepared by traditional method of ghee preparation from cream curd. It was tested in certified drug testing laboratory.

Lactose and glucose of Indian Pharmacopoeia (IP) grade were purchased from authentic source.

\section{Materials for bioavailability study}

Heparinized vacutainers [Sodium heparinN (NH) 75 USP Units blood collection tubes] were used for storage of blood prior to analysis. Savlon, medicated cotton, and band aid were purchased from surgical outlet. Nitric acid (ICP-MS grade), Hydrochloric acid (ICP-MS grade) were purchased from Fisher Scientific (India). Pipettes of transferpette brand were used for transfer of blood from vacutainers to digestion system stand. Standard gold solution of Sigma Aldrich was used as internal standard. Microwave digestion system of Mars 6 Model of CEM Corporation was used for acid digestion of blood. ICP-MS instrument of Agilent Technologies 7700 series was used for assessing gold levels in blood, having very low detection limits ranging from 0.1 parts per trillion to 1 parts per trillion.

\subsection{Methods}

\section{Bioavailability trial in healthy human participants}

Permission of institutional ethics committee was obtained (BVDUCOA/ EC /-1553/ 2015-16), and the trial was registered with Clinical Trials Registry of India (CTRI/2017/10/010135). This study was carried out by following the tenets of Declaration of Helsinki. Informed consent of all participants was obtained before the trial. For this exploratory randomized bioavailability trial, thirty healthy human participants (15 male and 15 female) were included from age group of 20- 40 years, having no acute or chronic health complaints, who did not consume any gold formulations nor consumed previously gold containing medicine since last 10 years and who had not taken any pharmaceutical medicine for last 6 months. Participants did not have any dental restorations of gold. Subjects consuming oral contraceptives, alcohol, smoking, and drugs of abuse were not selected. Selected participants were randomly allocated to five groups using chit method whereby each group had 3 male and 3 female participants as shown in table 1. 
Table 1 Study groups, group wise anupana, dose of gold bhasma, accompanying medium with amounts

\begin{tabular}{|l|c|l|c|}
\hline $\begin{array}{l}\text { Sr. No. } \\
\text { of group }\end{array}$ & $\begin{array}{l}\text { Dose of Gold } \\
\text { bhasma }\end{array}$ & $\begin{array}{l}\text { Anupana (accompanying } \\
\text { medium) }\end{array}$ & $\begin{array}{l}\text { No. of human } \\
\text { participants }\end{array}$ \\
\hline 1 & $30 \mathrm{mg}$ & Nil & 6 \\
\hline 2 & $30 \mathrm{mg}$ & Honey $[2.5 \mathrm{gm}]$ & 6 \\
\hline 3 & $30 \mathrm{mg}$ & $\begin{array}{l}\text { Black pepper powder } 250 \\
\text { mg + ghee } 2.5 \mathrm{gm}\end{array}$ & 6 \\
\hline 4 & $30 \mathrm{mg}$ & Lactose $[250 \mathrm{mg}]$ & 6 \\
\hline 5 & $30 \mathrm{mg}$ & Glucose $[250 \mathrm{mg}]$ & 6 \\
\hline
\end{tabular}

The subjects were asked to report in hospital at $6.30 \mathrm{am}$, NBM. One blood sample $(2 \mathrm{ml})$ was collected from cubital vein by dispovan syringe at $6.45 \mathrm{am}$, from each subject which was treated as 0 hour blood sample. Each participant of each group was administered $30 \mathrm{mg}$ gold bhasma. Except for the plain group rest of the doses of $30 \mathrm{mg}$ bhasma were thoroughly mixed with respective media viz. black pepper powder-ghee, honey, lactose and glucose in clean stainless steel bowls before administration for each volunteer separately. After five minutes, $100 \mathrm{ml}$ water was administered to subjects in all groups. Blood samples $(2 \mathrm{ml})$ were withdrawn after 1 hour, 3 hours and 5 hours respectively after administration of the dose of gold bhasma, and stored in heparinized vacutainers. Each time new site of venipuncture was selected in cubital vein, of right and left hand of each subject. The samples were stored in heparinized vacutainers and stored at $-20^{\circ} \mathrm{C}$.

During experiment there was standardization of study environment, diet, fluid intake, post dosing postures and blood sample withdrawal schedules. After 60 minutes of drug administration, standard breakfast [rich in carbohydrate and protein] was prearranged for all volunteers. The intension of breakfast after 60 minutes was to follow the actual clinical setting where patients usually consume rejuvenating medicines early in the morning and take breakfast after an hour. Lunch was administered after the last blood sample withdrawal. No major discomfort was noted while blood withdrawal from cubital vein while five blood samples were taken for study.

\section{Estimation of Blood Gold levels by ICPMS}

For estimation of $\mathrm{Au}$ in blood samples, a method published by Nanotechnology characterization laboratory, USA; has been followed [14].

\section{Acid digestion of blood sample [Figure 1]}

Acid digestion of whole blood samples was carried out as a prerequisite for ICP-MS testing of whole blood. Frozen blood samples $0.2 \mathrm{gm}$ each, were taken out of the $-20^{\circ} \mathrm{C}$ freezer and allowed to thaw at room temperature for approximately 2 hours. By using 'transferpette research pipette', each blood sample was transferred into a cleaned and tared microwave vessel. Each blood sample was accurately weighed by difference to get blood mass. Six cleaned microwave vessels were kept for the preparation of 6 procedure blanks. $4 \mathrm{ml} \mathrm{HNO}_{3}$ and $1 \mathrm{ml} \mathrm{HCl}$ were added into each microwave vessel. Microwave vessels were capped and installed in the turntable. All the positions of the turntable were utilized. Programming of the microwave was done according to protocol. After the digestion protocol was over, microwave vessels were allowed to cool inside microwave oven. Then the microwave turntable was taken out of oven, and placed in a hood. Each microwave vessel was opened slowly to allow gentle release of gas of the digestion. The contents of the vessels (digest) were transferred to pre weighed low density polyethylene (LDPE) bottles.

\section{Testing of digested blood by ICPMS}

Various concentrations of standard Au solution were prepared as internal standards. With the help of reference standard the digested samples were tested by ICP-MS for Au content. 


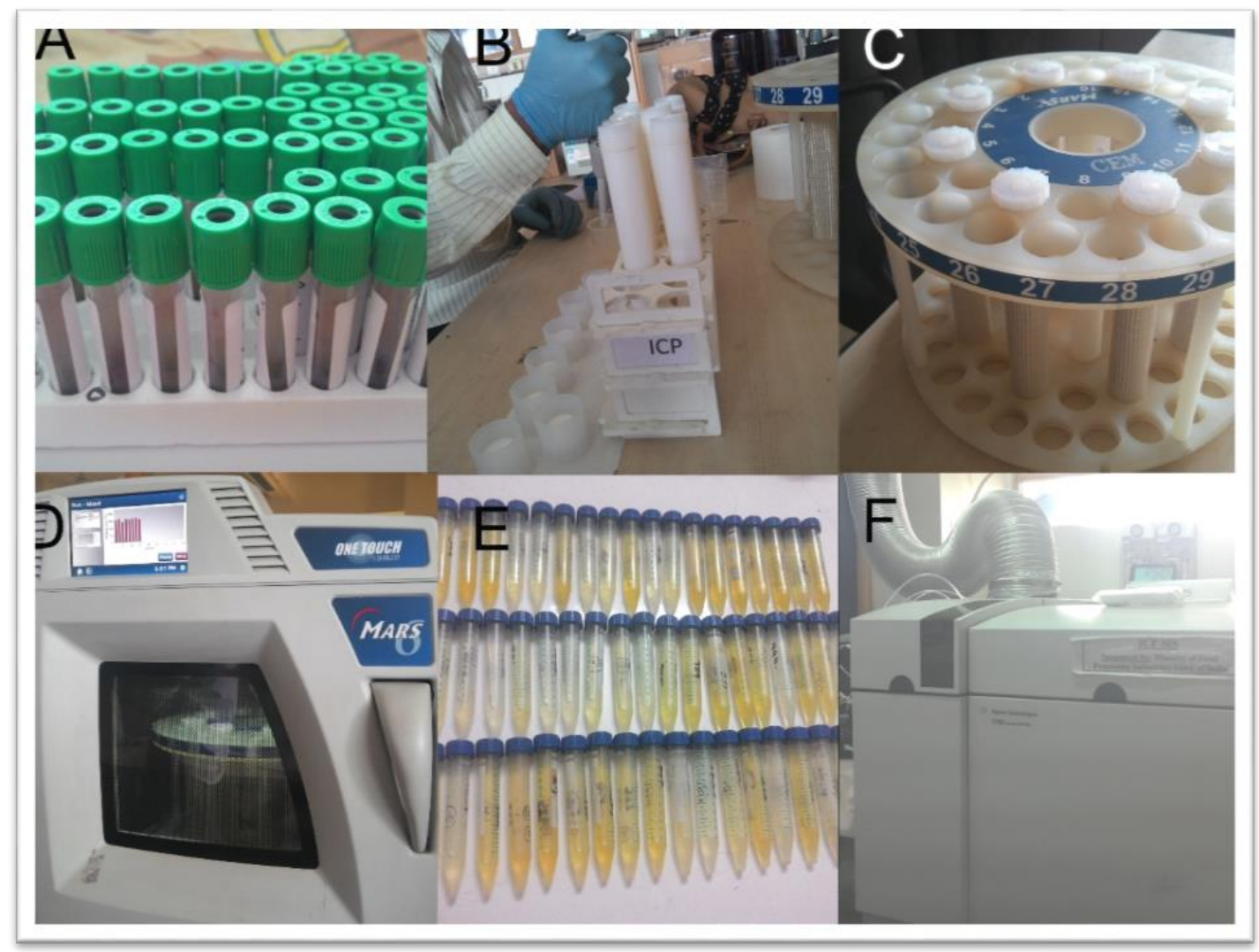

Figure 1 Images of A] blood samples in heparinized vacutainers, B] Acids being added to blood sample C]Microwave vessels, C] Microwave digestion system, D] Digested blood samples, F] ICP-MS machine for estimation of Au levels in digested blood samples

\section{Results and discussion}

\subsection{Results of authentication of honey, black pepper and ghee}

Table 2 Authentication of honey

\begin{tabular}{|l|l|l|l|}
\hline Sr. No. & Test & Obtained value & Standard (API) \\
\hline 1 & Description & $\begin{array}{l}\text { Brown coloured thick liquid with } \\
\text { characteristic smell }\end{array}$ & Brown, thick \\
\hline 2 & Weight per ml & $1.40 \mathrm{gm}$ & NLT $1.35 \mathrm{gm}$ \\
\hline 3 & Moisture content & $12.58 \%$ & NMT $25 \%$ \\
\hline 4 & PH & 6.01 & NA \\
\hline 5 & Acid value & 0.89 & NA \\
\hline 6 & Viscosity & $14095 \mathrm{p}$. pas. & NA \\
\hline 7 & Specific gravity & 1.974 & NA \\
\hline 8 & Refractive index & 1.557 & NA \\
\hline 9 & Conductivity & $0.502 \mathrm{~ms} / \mathrm{s}$ & NA \\
\hline 10 & Total viable count (microbial analysis) & 86 & NA \\
\hline 11 & Total fungal count & Nil & NA \\
\hline
\end{tabular}


Upon burning of a wick soaked in honey; there was no burnt sugar or burnt jaggery like smell. The sample of honey complied with the API standards.

Table 3 [additional] -Results of HPTLC of piperine (pure standard)

\begin{tabular}{|c|c|c|c|c|l|}
\hline Sr. No. & Peak No. & Concentration & Wavelength & Rf Value & Area \\
\hline 1. & 2 & $5 \times 105 \mathrm{ng} / \mathrm{spot}$ & $254 \mathrm{~nm}$ & 0.78 & $5816.6 \mathrm{AU}$ \\
\hline
\end{tabular}

Table 4 Results of HPTLC of sample of marica (Dried fruits of Piper nigrum L.)

\begin{tabular}{|l|l|l|l|l|l|}
\hline Sr.No. & Peak No. & Concentration & Wavelength & Rf Value & Area \\
\hline 1. & 2 & $1 \times 107 \mathrm{ng} / \mathrm{spot}$ & $254 \mathrm{~nm}$ & 0.78 & $9942.8 \mathrm{AU}$ \\
\hline
\end{tabular}

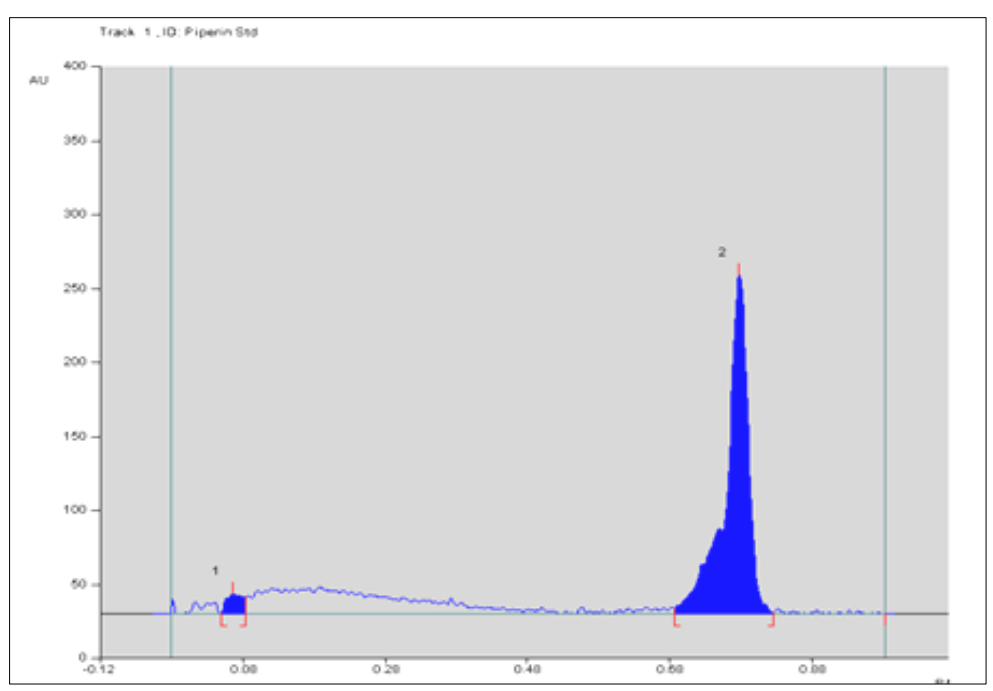

Figure 2 Image showing HPTLC of Piperine (pure standard)

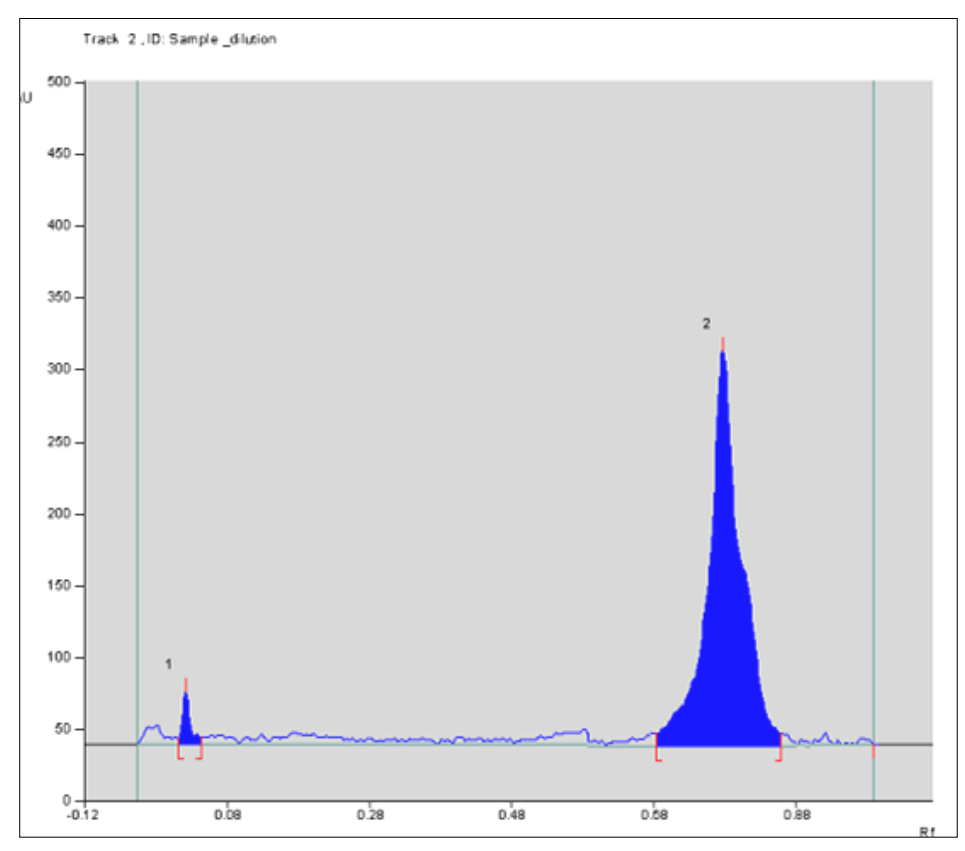

Figure 3 Image showing HPTLC of sample of marica (Dried fruits of Piper nigrum L.) 
Table 5 Tests of black pepper as per the API

\begin{tabular}{|l|l|c|}
\hline Tests of Marich [black pepper dried fruits] & Standard values (API) & Result \\
\hline Colour & Brown & Brown \\
\hline Loss on drying & - & $8.32 \%$ \\
\hline Foreign matter & NMT 2\% & $0 \%$ \\
\hline Total ash & NMT 6\% & $3.9 \%$ \\
\hline Alcohol soluble extractives & NLT 5\% & $7.72 \%$ \\
\hline Water soluble extractive & NLT 9\% & $40.67 \%$ \\
\hline Volatile oils & NLT 3 & $3 \%$ \\
\hline PH value & - & 6.31 \\
\hline
\end{tabular}

It was evident that the sample of marica was authentic having optimum piperine content and complies with the standards in API.

Table 6 Authentication of cow's ghee

\begin{tabular}{|l|c|}
\hline \multicolumn{2}{|c|}{ Analysis of nutritional factors from Cow Ghee } \\
\hline Description & Yellow coloured thick liquid \\
\hline TEST & Value per $100 \mathrm{gm}$ \\
\hline Energy & $891 \mathrm{kcal}$ \\
\hline Protein & $1.22 \mathrm{gm}$ \\
\hline Carbohydrates & $0.26 \mathrm{gm}$ \\
\hline Fats & $98.32 \mathrm{gm}$ \\
\hline Saturated fatty acids & $70.12 \mathrm{gm}$ \\
\hline Trans fatty acids & 0 \\
\hline Cholesterol & $0.363 \mathrm{gm}$ \\
\hline Vitamin A & $1706 \mathrm{IU}$ \\
\hline
\end{tabular}

Table 7 Authentication of cow's ghee

\begin{tabular}{|l|c|c|}
\hline Test of cow ghee & Value & Standard (API) \\
\hline Colour & Yellow & Yellow \\
\hline Specific gravity & 0.916 & 1.01 at $25^{\circ} \mathrm{C}$ \\
\hline Saponification value & 224 & NMT 225 \\
\hline Acid value & 0.66 & NA \\
\hline PH & 5.42 & NA \\
\hline Viscosity & 32 & NA \\
\hline Moisture content & $0.3 \%$ & NMT $0.5 \%$ \\
\hline Refractive index & 1.534 & NA \\
\hline Peroxide value & 7.65 & NA \\
\hline Iodine value & 5.01 & NA \\
\hline Loss on drying & 0.17 & NA \\
\hline Total viable count (microbial analysis) & Nil & NA \\
\hline Total fungal count & Nil & NA \\
\hline
\end{tabular}




\subsection{Results of bioavailability study}

The data of absorption of Au from the drug is presented in table 2

Table 8 Data of mean absorbance in all 5 groups

\begin{tabular}{|c|l|l|c|c|c|}
\hline $\begin{array}{c}\text { Anupāna of Gold } \\
\text { Bhasma } \\
\text { Time in hours }\end{array}$ & $\begin{array}{l}\text { Plain } \\
\text { gold } \\
\text { bhasma }\end{array}$ & Honey & $\begin{array}{l}\text { Black pepper powder } \\
\text { +Ghee }\end{array}$ & Lactose & Glucose \\
\hline & \multicolumn{1}{|l|}{ Au levels in blood in 'microgram per litre [ppb]' as obtained by ICP-MS } \\
\hline 0 hour & 0.0013 & 0.002 & 0.002 & 0.0006 & 0 \\
\hline 1 hour & 0.000167 & 0.0015 & 0.000333 & 0.000667 & 0 \\
\hline 3 hours & 0.000667 & 0.002333 & 0.000333 & 0 & 0.000667 \\
\hline 5 hours & 0 & 0.000167 & 0 & 0 & 0 \\
\hline
\end{tabular}

Table 8- The table shows average blood Au levels per group for five groups after administration of -1]Plain gold bhasma $30 \mathrm{mg}$, 2] gold bhasma $30 \mathrm{mg}$ with black pepper and ghee [250 mg, $2.5 \mathrm{gm}$ respectively, 3] gold bhasma $30 \mathrm{mg}$ with honey [2.5 gm], 4] gold bhasma $30 \mathrm{mg}$ with lactose [250 mg]; and 5]gold bhasma $30 \mathrm{mg}$ with glucose [250 mg]. The estimation of $\mathrm{Au}$ levels in blood samples was by ICP-MS

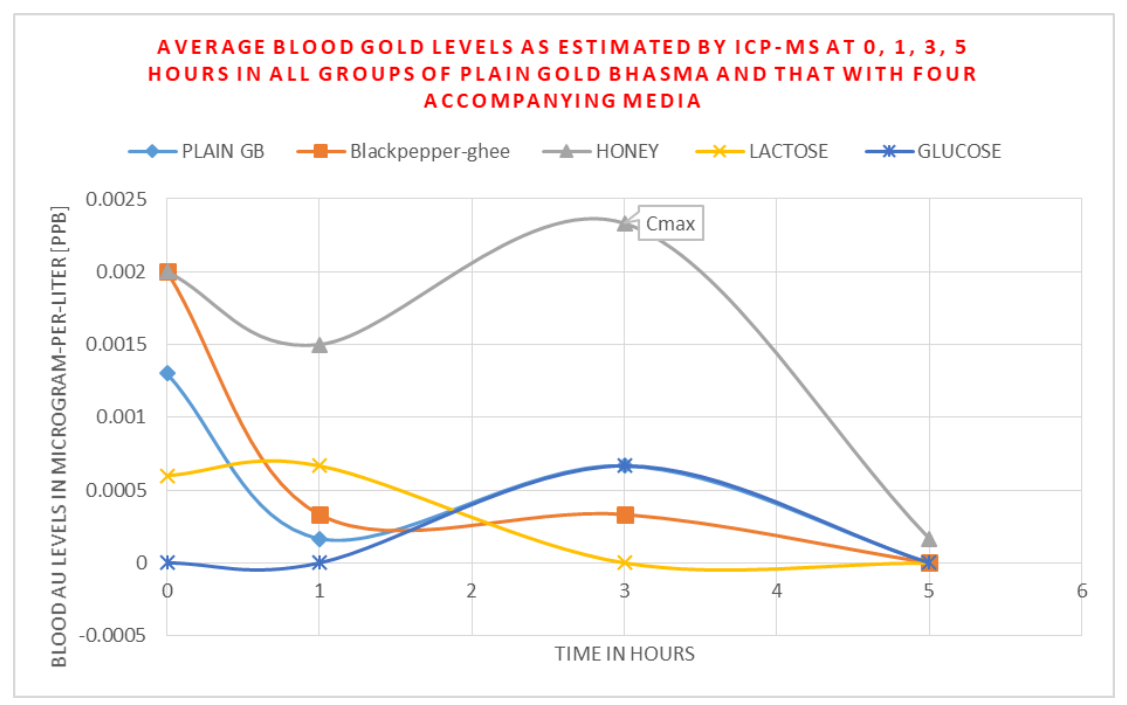

Figure 4 First step of pharmacokinetic profile, showing bioavailability curves of Gold bhasma upto five hours after administration of Gold Bhasma [30 mg oral dose] with four different anupāna [honey, black pepper-ghee, lactose and glucose] and plain water. Analysis of blood samples by ICP-MS shows maximum $\mathrm{C}_{\max }$ was attained for honey as anupana [vehicle drug or medium] in comparison with other media studied in present investigation of gold bhasma.

The average Au levels in blood were plotted as a chart showing curves of bioavailability as seen in figure 4. It was evident that there were some traces of gold in 0 hour blood samples. Due to these traces already present in blood samples the possibility of unknown sources of gold was established. It is hence not possible to plot accurate area under curve (AUC) considering the fact that the determined Au levels at 1, 3, and 5 hours were also in parts per billion range (traces).

Simultaneous comparisons of all groups at once was carried out by ANOVA. T test was used for comparison of every two groups at each time interval. It is indicated by two way ANOVA that accompanying medicaments significantly affect bioavailability of gold from gold bhasma. There is significant difference in Au concentration in blood among all groups at 1 and 3 hours. The maximum $C_{\max }$ among all samples tested was 0.00233 microgram per litre, which is very minute $(<0.01 \%)$. Hence there is some uncertainty in measurement. Unpaired t-test was used for comparison between each two groups. It is evident by t-test that there was significant difference at 1 hour after dose between groups viz. 
- Gold bhasma mixed with honey and gold bhasma mixed with black pepper-ghee.

- Gold bhasma mixed with honey and plain gold bhasma.

- Gold bhasma mixed with honey and gold bhasma mixed with lactose.

- Gold bhasma mixed with honey and gold bhasma mixed with glucose-

- Gold bhasma mixed with lactose and gold bhasma mixed with glucose.

The significant difference between all groups at 1 hour indicates that accompanying medium may affect the bioavailability of gold from the Ayurvedic gold bhasma. At 1 hour gold bhasma mixed with honey exhibited maximum absorbance. It is evident by $t$ test that there is significant difference at 3 hours in following two groups viz.

- gold bhasma + lactose and gold bhasma + glucose,

- Plain gold bhasma and gold bhasma + lactose

$\mathrm{T}_{\max }$ is marked at 3 hours clearly in case of group of gold bhasma with honey.

\section{Discussion}

This study is a preliminary report of estimation and comparison of bioavailability of Ayurvedic medicine 'gold bhasma'. The drug was administered with four media, and plain in human participants as a single dose. The minimum amount of gold obtained was zero and maximum was 0.002333 microgram per litres. This makes it clear that as the amounts of $\mathrm{Au}$ in blood after administration were very scanty it is essential to discuss probable reasons. ICP-MS [Inductively coupled plasma mass spectrometry] was used as tracer technique for Au in blood which is extremely sensitive to detect amounts as low as 'few parts per billion' of element under investigation. It is concluded from this study that Au may be absorbed in traces from single oral dose of gold bhasma. In this study there were some traces of gold in blood samples before administration of drug, even though participants have not consumed gold medicines since at least 10 years. The participants did not have dental gold restorations. Presence of gold in sample before dose administration is attributed to unknown reasons from probably food and water [15]. The percentage of gold in soil, water, foods etc in the region of study may be estimated to get an idea. It has been reported in that according the technical treatise, 'The Elements', in third edition, written by John Emsley and published by the Clarendon Press, Oxford in 1998, the average person's body weighing 70 kilograms would contain a total mass of 0.2 milligrams of gold. The volume of this gold in purified form would be 10 nanoliters [16]. Hence there is a normal trace level of gold present in biological fluids of humans.

Even after dosing the levels are noted to be in traces. In modern science it is well known that at times oral administration does not always give rise to sufficiently high plasma concentrations, some drugs are absorbed unpredictably or erratically and patients occasionally have an absorption malfunction [17 NEW pp 1156, Remington, The science and practise of Pharmacy, $21^{\text {st }}$ edition, and reprint 2006]. Hence further research is necessary to answer the questions raised by this study.

Testing of biological sample viz blood requires acid digestion as a prerequisite for ICP-MS testing. During the digestion of blood samples organic cell walls of blood cells get destroyed by acid [HCL and $\mathrm{HNO}_{3}$ ] and only inorganic elements remain in the digested material which is further analyzed by ICP-MS. Hence whole blood sample was analyzed so that complete gold level in plasma and in blood cells could be determined at once. ICP-MS measures the total Au content in whole blood including blood cells and serum, considering the possibility that gold bhasma particles may have been taken up by blood cells.

Absorption of metals through GIT depends on many factors like chemical nature and coating, accompanying substances and drug delivery system. Bioavailability of gold nanoparticles made by modern methods has been studied and is reported to be very less. These nanoparticles are prepared mainly by reduction of gold salts. It is known that bioavailability of PEG (polyethylene glycol) coated gold nanoparticles in rats is very low $(<0.1 \%)$ [18]. Smith et al 2013 [7] have studied the oral bioavailability of $2.0 \mathrm{~nm}$ diameter gold nanoparticles modified with the small molecules pmercaptobenzoic acid and glutathione, and polyethylene glycols (PEG) of different lengths and charge (neutral and anionic). They concluded that gastrointestinal absorption of gold nanoparticles modified with the small molecules tested was undetectable [7]. There has been study on how the bioavailability of nanoparticles can be improved by preparing lipid based nanoparticles [19]. Another chrysotherapy drug viz orally administered auranofin has shown low bioavailability ie about $15-25 \%$ [6].

It is reported that Ayurvedic swarnabhasma [gold bhasma] is comprised of nano-particles of gold [2,3]. It is delivered by oral route directly or sublingually by some physicians. In recent advances, modern age gold nanoparticles are generally administered intravenously instead of orally due to negligible oral absorption and cellular uptake. In a study 
that evaluated the oral bioavailability of gold nanoparticles coated with chitosan (C-AuNPs) in rats, a natural mucoadhesive polymer, the oral bioavailability of C-AuNPs was found to be $2.46 \%$ which is approximately 25 folds higher than polyethylene glycol (PEG) coated gold nanoparticles, reported earlier [20].

The accompanying medium, which itself also possesses medicinal properties does play a role in pharmacokinetics of drug. Generation of evidence for such role is needed. Anupana disintegrates the particles of main drug like powder or bhasma [vibhaktah paramanava], and it is said to cause a fast distribution of drug in body [drutamangeshu sarpanti] as per the verse from Rasatarangini. Anupana is supposed to enhance the main drug [paribruhan] [21] NEW [RT reference]. In clinical practise according to vaidya's wisdom, for kapha dosha dominant disease, honey may be used as anupana. For pitta dosha dominant disease ghee may be used as anupana with other curative medicine. This is because honey is naturally curative for enhanced kapha. Highly viscous nature, slightly acidic $\mathrm{pH}$ [6.01], presence of natural sugars make it a unique vehicle drug [anupana]. Ghee is naturally curative for enhanced pitta dosha. Ghee is lipoid in nature, has capacity to cross the blood brain barrier, and is recommended for persons who wish to enhance intellect, memory, and digestive capacity [agni] as indicated in Ashtanghruday. Interestingly, honey and ghee are the most commonly used anupana. Sesame oil is naturally curative for vata dosha. It is specific anupana for formulations like rason kalka, rasnadi kwatha. At times there are formulation specific anupanas, irrespective of the dosha states. However oil has not been reported as anupana for gold bhasma. Wherever, anupāna or sahapāna are not specified for a formulation, honey and water may be taken (21 Rasatarangini, Sharma Sadananda, 1989). Mixing the drugs with bioavailability enhancer like black pepper [22] or with lipid media is a common practice while administration of bhasma. Piperine from black pepper is known as effective bioavailability enhancer for some drugs. However honey might to be the maximum effective medium in case of gold bhasma, due to its viscous nature, acidic $\mathrm{pH}$, thinning out ability and ushna guna. It offers best dispersion of agglomerated bhasma particles. Ghee is lipid medium with ability to cross blood brain barrier. Black pepper possesses sharp penetrating action, and bioavailability enhancer activity [22, 23]. Further research can explore how the pharmacokinetics of Gold Bhasma is affected with various anuapnas.

Herein the comparative bioavailability of $30 \mathrm{mg}$ oral dose mixed with honey indicated probable higher absorption in comparison with other accompanying media. The maximum $\mathrm{C}_{\max }$ in case of honey suggests honey as the most effective medium due to its unique viscous nature, spreading ability and kapha reducing properties. In all groups, Tmax was at 3 hours. Gold bhasma mixed with glucose and lactose resulted in nil to negligible amounts of Au in blood. This is suggestive of the importance of anupana in case of gold bhasma. It is recommended to use honey instead of these media. Further exploration of pharmacokinetics and efficacy is necessary for knowing tissue distribution, organ distribution, and mechanism of action and excretion of gold bhasma.

Particles of gold bhasma float over water and are absolutely insoluble in it. Aqueous insolubility of gold bhasma may attribute to its low bioavailability. Ayurvedic text Rasaprakashsudhakar has reported a guideline of consumption of gold bhasma for upto 20 years [24] in $60 \mathrm{mg}$ daily dose for longevity. Long term consumption may lead to cellular entry of gold bhasma particles in cells [3], which needs exploration. Hence steady state concentration study would be essential in case of gold bhasma. For the drugs having low or negligible bioavailability, steady state concentration studies are recommended. This means that the drug is administered daily until a steady blood concentration is achieved. This is an approach to study the absorption of drugs used for long term treatment. As gold bhasma has been recommended for a long term use [24] upto 20 years, further research in this area is required. Steady state concentration study to check how much duration is required to obtain a steady state of drug in blood may be helpful to draw important conclusions for wider use of Swarnabhasma.

There is may be significant variation in pharmacokinetics when around 60 different accompanying media for gold bhasma, with well documented functions as mentioned in ancient Sanskrit manuscripts. It is claimed that the Ayurvedic media like ghee, honey etc act as vehicles towards the target organs. Further pharmacokinetic exploration is required.

Though gold bhasma is not a new drug, it is important to note that there are multiple different processes to manufacture it [25-29], and hence the chemical composition is different of each type of gold bhasma. The gold bhasma in present study manufactured by method from 'Bharat Bhaishajya Ratnakar' [25], and comprises of $95 \%$ pure gold as investigated by us.

It is important to note that cytotoxicity is strongly dependent on the exact nature of the gold nanoparticles [29]. Gold bhasma is used as medicine for longevity and rejuvenation since thousands of years. Researches on gold nanoparticles also report about their cellular take up by cells and their safety [30]. Mitra et al in 2012 have demonstrated the safety of bhasma of gold prepared using another process which involves use of lead. Aspects related to cellular entry and effects on biological processes need to be studied by further exploration. 
Gold bhasma is used as a rasayan [rejuvenator] and also for treatment of cancer and other debilitating diseases by Ayurvedic physicians. The applications of AuNPs for cancer management are being studied all over the world. Considering this fact further scientific exploration gold bhasma of Ayurveda is needed for wider medicinal use.

\section{Conclusion}

It is concluded that Au levels in blood were of trace level upto five hours after administration of 30 mg bhasma of gold metal and it is suggested that bioavailability of gold from gold bhasma may be less than $0.01 \%$ upto first five hours after oral administration. Results of the preliminary study indicate that honey may prove to be efficient medium than the other media like lactose, glucose, black pepper and ghee in case of Swarna bhasma. It was observed that $\mathrm{T}_{\max }$ was attained at 3 hours for Gold bhasma. It is essential to conduct steady state concentration study of Gold Bhasma because long term use of this drug is recommended for rejuvenation. Further research is necessary to understand complete pharmacokinetics of Gold Bhasma.

\section{Compliance with ethical standards}

\section{Acknowledgments}

The authors are grateful to Shree. Dhootapapeshwar Limited, Panvel for providing Gold Bhasma for this research. Authors are thankful to Dr. L. Sathianarayan of Poona College of Pharmacy for his assistance for HPTLC test.

\section{Source of funding}

The authors are grateful to Bharati Vidyapeeth (Deemed to be University), Pune for financial support [Grant no. 929]

\section{Disclosure of conflict of interest}

There are no conflicts of interest.

\section{References}

[1] Yadavji T, Editor. Charaksamhita of Agnivesha, Chikitsasthana Ch. 23 Ver. 240-241, Reprint 2011, Varanasi: Chaukhambha Prakashan. 2011; 581.

[2] Brown CL, Bushell GR, Michael W, Whitehouse MW, Agrawal DS, Paknikar KM, Tiekink E. Nano Goldpharmaceutics(i) The use of colloidal Gold to treat experimentally-induced arthritis in rat models; (ii) Characterization of the Gold in Swarnabhasma, a microparticulate used in traditional Indian medicine, Gold bulletin. 2007; 40(3): 245.

[3] Beaudet D, Badilescu S, Kuruvinashetti K, Kashani A, Jaunky D, Ouellette S, Piekny A, Packirisamy M. 'Comparative study on cellular entry of incinerated ancient gold particles (Svarṇa bhasma) and chemically synthesized gold particles', Scientific Reports 7. 2017.

[4] Remington's the science and practise of pharmacy, 21 st edition. 1038.

[5] Patil-Bhole T, Patil S, Wele A. Assessment of bioavailability of Svarna bhasma in human participants - A pilot study., J Ayurveda Integr Med. Oct - Dec 2018; 9(4): 294-297.

[6] Schattenkirchner M, Bröll H, Kaik B, Müller-Fassbender H, Rau R, Zeidler H. Auranofin and Gold Sodium Thiomalate in the Treatment of Rheumatoid Arthritis: A One-Year, Double-Blind, Comparative Multicenter Study, Klin Wochenschr. 1988; 66(4): 167-74.

[7] Furst DE, Dromgoole SH. 'Comparative pharmacokinetics of triethylphosphine gold (auranofin) and gold sodium thiomalate (GST)', Clin Rheumatol. Mar 1984; 3(1): 17-24.

[8] Smith CA, Simpson CA, Kim G, Carter CJ, Feldheim DL. 'Gastrointestinal bioavailability of $2.0 \mathrm{~nm}$ diameter gold nanoparticles'. ACS Nano. 28 May 2013; 7(5): 3991-6.

[9] Patil T, Wele A, and Review on therapeutic potential of āyurvedika medicine svarnabhasma (incinerated gold)' IAJPS 2018, 5(1): 192-205.

[10] Yadavji T, Editor, Sushrutsamhita of Sushruta, Chikitsashthana, Ch. 28 Ver. 14-24, 4th edition, Varanasi Chaukhambha Orientalia. 1980; 501-502. 
[11] Kulkarni DA, editor, Rasaratnasamucchay of Vagbhat, Ch. 5 Ver., New Delhi : Meharchand Lakshmandas Publications. 1942; 92-96.

[12] Shah NC, Bharat Bhaishjya Ratnakar Part 5, formulation ver. no. 8357, New Delhi: B. Jain Publishers, Reprint. 2005; 418.

[13] Mendham, Vogels Quantitative chemical analysis. 2009; 456-457.

[14] http://www.nist.gov/publication/get_pdf/ NIST _NCL Joint assay protocol -PCC 9, Version 1.1 viz. ' Determination of Gold in rat blood with Inductively Coupled Plasma Mass Spectrometry' was used for reference of methodology for estimation of Au content in blood sample. [accessed on 21/01/2014]

[15] McHugh JB, Concentration of gold in natural waters, Journal of Geochemical Exploration. 1988; 30(1-3): 85-94.

[16] NEW [ 17 NEW pp 1156, Remington, The science and practise of Pharmacy, 21 st edition, reprint 2006].

[17] https://www.gold-traders.co.uk/gold-information/how-much-gold-is-found-in-the-human-body.asp, date accessed : 8/04/2020]

[18] Alalaiwe A, Roberts G, Carpinone P, Munson J, Roberts S, Influence of PEG coating on the oral bioavailability of gold nanoparticles in rats. Drug Deliv. Nov 2017; 24(1): 591-598.

[19] Wang T, Luo Y. Biological Fate of Ingested Lipid-Based Nanoparticles: Current Understanding and Future Directions, Nanoscale. 21 Jun 2019; 11(23). 11048-11063,

[20] Alalaiwe A, Carpinone P, Alshahrani S, Alsulays B, Ansari M, Anwer et al, Influence of chitosan coating on the oral bioavailability of gold nanoparticles in rats. Saudi pharmaceutical journal: SPJ: the official publication of the Saudi Pharmaceutical Society. 27(2): 171-175.

[21] Sharma Sadananda, Rasatarangini, Ed. Shatri Kashinath, Motilal Banarasidas Publication, 11th Edition, Reprint. 1989. verse 15/28, verse no 15/69, 15/71-80, 367, 375, 376.

[22] Patil T, Wele A, Significance of pharmacokinetics and pharmacodynamics of Piper nigrum L. [Marich] as an ingredient and possible marker of Ayurvedic formulations, Indian Drugs. 2007; 44(5): 329-336.

[23] Khajuria A, Zutshi U, Bedi KL, 'Permeability characteristics of piperine on oral absorption-an active alkaloid from peppers and a bioavailability enhancer’, Indian J Exp Biol. Jan 1998; 36(1): 46-50.

[24] Mishra S, Translator, Rasaprakash Sudhakar of Acharya Yashodhar, Ch. 4, Ver. First edition, Varanasi: Choukhambha Orientalia. 1983; 67, 68, 69.

[25] Shah NC, Bharat Bhaishjya Ratnakar Part 5, B. Jain Publishers, Reprint 2005, New Delhi, India, 2005 ; $415-420$.

[26] Mitra A, Chakraborty S, Auddy B, Tripathi P, Sen S, Saha AV, Mukherjee B. Evaluation of chemical constituents and free-radical scavenging activity of Swarnabhasma (Gold ash), an Ayurvedic drug, J Ethnopharmacol. May 2002; 80(2-3): 147-53.

[27] Khedekar S, Anupriya, Galib R, Patgiri B, Prajapati PK. 'Chemical characterization of incinerated Gold', Advances in Applied Science Research. 2015; 6(12): 89-95

[28] Paul W, Sharma CP. Blood compatibility studies of Swarna Bhasma (Gold bhasma), an Ayurvedic drug, Int J Ayurveda Res. Jan 2011; 2(1): 14-22.

[29] Schleh C, Semmler-Behnke M, Lipka J, Wenk A, Hirn S, Schäffler M, Schmid G.,2 Simon U and Kreyling W, Size and surface charge of gold nanoparticles determine absorption across intestinal barriers and accumulation in secondary target organs after oral administration Nanotoxicology. Feb 2012; 6(1): 36-46.

[30] Connor E, Mwamuka J, Gole A., Murphy C. Wyatt M Gold Nanoparticles Are Taken Up by Human Cells but Do Not Cause Acute Cytotoxicity, Nano Micro Small. 28 January 2005. 